\title{
Growers strive to reduce selenium discharges
}

To an unprecedented project, growers in the $1_{\text {western San Joaquin Valley have taken re- }}$ sponsibility for reducing the amount of selenium they discharge into the San Joaquin River - an ambitious goal since weather variations like El Niño can play havoc with the level of naturally occurring selenium in their drainage water.

When they succeed, they ameliorate longstanding problems of selenium-laden drainage waters which can poison wildlife. When they fail, they and their water districts can pay yearly fees of up to $\$ 250,000$.

This unusual arrangement developed 2 years ago when Grassland Basin growers received permission to reopen a 28-mile portion of the San Luis Drain. The canal had been closed since 1986 when selenium-loaded drainage from Westlands Water District was tied to birth defects in Kesterson Reservoir waterfowl. (The drain now empties into Mud Slough, which flows into the San Joaquin River.)

The U.S. Bureau of Reclamation, U.S. Fish and Wildlife Service, U.S. Environmental Protection Agency, California Department of Fish and Game and the Central Valley Regional Water Quality Control Board oversee the Grasslands Bypass Project.

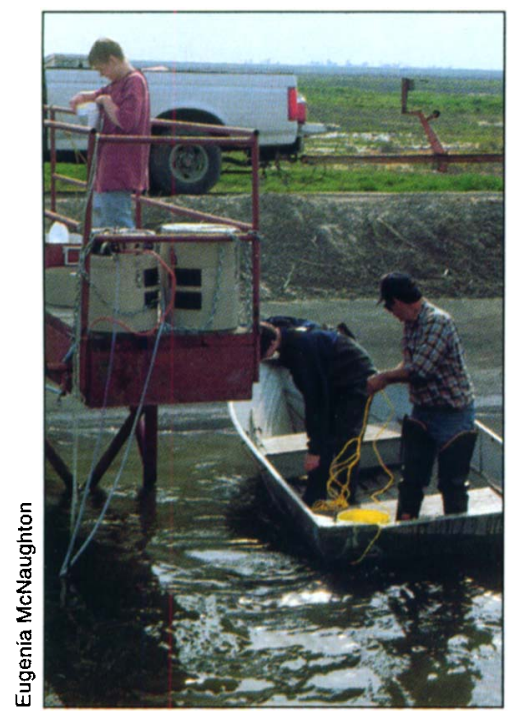

This project has several major benefits according to Nigel Quinn, a Lawrence Berkeley National Laboratory water resources scientist, who has worked on the project since its inception in 1991. It diverts agricultural drainage from freshwater channels serving private wetlands and duck clubs within the Grassland Water District, reducing the requirement for flushing, saving water and reducing the risk of wildlife exposure to selenium. It also improves water quality in Salt Slough, a source of water to state and federal refuges in the Basin. It allows much more accurate monitoring of flow and salt and selenium loads.

To use the federally owned canal, growers are expected to meet strict monthly and annual selenium load tarwater in the San Luis Drain before it enters Mud Slough. gets. A multidisciplinary group of scientists has developed a comprehensive compliance moni- toring program to evaluate the project's impacts on flow, water quality, sediments and biota.

The monthly and annual load targets for the 97,000 -acre drainage service area were established through negotiations between state and federal agencies, environmental groups, the water districts and their representatives involved in the project. Incentive fees of up to $\$ 250,000$ per year can be levied on the water districts if they exceed the annual load target. Monthly selenium targets have also been established and carry an additional fee of up to $\$ 250,000$ if exceeded by $20 \%$. Exceeding the annual target by more than $20 \%$ in normal years would trigger reevaluation and possible termination of the Grasslands Bypass Project. Allowance is made for uncontrollable and unforeseen hydrologic events, such as the flood of 1998.

"The growers and water districts have been the major players in this project," says Quinn. "They have probably achieved more in the application of new techniques and improved management practices in this past year than during the past decade."

Although they paid $\$ 60,000$ during the rainy season of the first year of this 5-year project for exceeding the targets, Quinn says, Grassland Basin farmers successfully reduced selenium export by $44 \%$ and $33 \%$ as compared to water years 1995 and 1996 (see page 12).

Water districts have reduced the amount of drainage by improving on-farm water management, adopting water conserving practices and investing in facilities to recycle drainage water. Examples of these actions are the elimination of tailwater from district drainage facilities, grower and ditch-tender workshops to share improved water management techniques and the installation of real-time sensors for flow and water quality monitoring.

Despite the growers' efforts, drainage waters have exceeded selenium load targets in 1998 for unknown reasons. "It remains to be seen over the next 3 years how well selenium loads are being reduced," says USFW contaminant specialist Tom Maurer.

Scientists from state and federal agencies are monitoring sediment and biological changes. 
The purpose of the sediment monitoring program is to observe patterns of sediment deposition in and movement through the San Luis Drain and the Mud and Salt sloughs to assess changes in the selenium concentrations of these sediments.

Biologists are analyzing aquatic food-chain plants and animals for potential effects on fish or wildlife resources. They also are testing gamefish to assess risks to people who eat fish from the sloughs or river in the vicinity of the project area.

"We found more or less what was expected: there was less contamination in sloughs where drainage water used to be diverted and a major increase in the slough below where the drain empties," says USFW biologist Bill Beckon.

"We saw a steep spike in selenium levels in mosquito fish when the drain was reopened," Beckon says. Selenium levels in the fish have dropped in Mud Slough since the water districts began managing drainage releases to reduce selenium load, but the levels are still elevated.

Analysis of carp fillets from Mud Slough showed that selenium levels did not pose a risk for human consumption. Although carp is not the most popular gamefish, the biologists chose to monitor it because it is consistent to all sites, and will provide useful spatial and temporal trend information. Whole-body selenium levels in Sacramento squawfish, threadfin shad, Sacramento blackfish and red shiners have risen to levels of concern for the fish.

Biologists are also monitoring any changes in the different fish species that make up the aquatic community. "The general consensus based upon preliminary data is we're not seeing a huge change," says Mary

Dunne, a Fish and Game biologist. "After one year of project operation, both the slough and river sites appear to be sustaining functionally diverse fish communities."

The biologists are also measuring selenium in the vegetation and invertebrates that waterfowl eat. Water boatmen and crayfish caught below the drain had increased levels of selenium.

"Since the drain opened, the levels in the crayfish moved into that gray area of concern. With invertebrates, we're looking at food-chain effects. Those effects are delayed," Beckon says, noting that birds concentrate the selenium into their eggs.

Fish and Wildlife biologists have begun collecting the eggs of ducks, killdeer, avocets, black-necked stilts, pheasants, snowy egrets, night herons, bitterns and barn swallows.

Toxicity tests run monthly help to determine whether exposure to water in the project harms aquatic animals. No consistent findings have emerged yet, according to EPA environmental scientist Eugenia McNaughton. - Editor

\section{Plants, algae and microbes help clean up selenium}

UC Berkeley plant biologist Norman Terry is investigating how efficiently wetlands filter out selenium from drainage water. At a site in Corcoran, Terry planted quarter-acre wetland cells with single and combinations of plant species.

In the 1998 season, the average selenium concentration in the drainage water was 22 parts per billion. Terry found that, flowing drainage water through the cells for 7 days, selenium remediation ranged from $30 \%$ in the unplanted cell and cells planted with cordgrass, salt grass and a combination of bulrush and tule, to as much as $60 \%$ in the combination cell planted with cattail and widgeon grass.

UC Berkeley engineer William Oswald and his group have been using algae and bacteria to trap selenium in a 10,000 -gallon-per-day treatment system in the Panoche Water District in
Fresno County. As the algae grow, they take up the nitrate from the drainage water. When the nitrate levels are low, bacteria can precipitate the selenium removing it from the water. Soluble selenium removals by the system have averaged over $90 \%$ this summer.

UC Riverside microbiologist William Frankenberger, Jr., is testing a method of detoxifying selenium-tainted sediments obtained from the San Luis Drain using naturally occurring microbes. The patented technique, developed by his lab, supercharges the process by aerating the sediment, adding carboncontaining amendments such as pectin and proteins and maintaining field-moist conditions. As much as $46 \%$ of the selenium has been removed in 10 months with the addition of proteins.

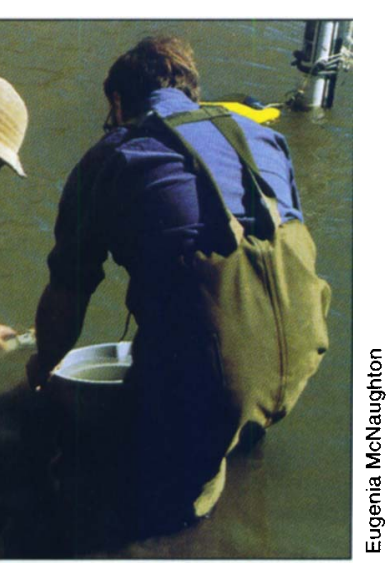

U.S. Fish and Wildlife Service biologists remove fathead minnow from a 7-day in situ survival test in the Grasslands Bypass Project.

.

